\title{
Effect of the organochlorine pesticide technical chlordane on the population structure of suspension and deposit feeding bivalves
}

\author{
R. D. Pridmore ${ }^{1}$, S. F. Thrush ${ }^{1}$, R. J. Wilcock ${ }^{1}$, T. J. Smith ${ }^{2}$, J. E. Hewitt ${ }^{1}$, \\ V. J. Cummings ${ }^{1}$ \\ ${ }^{1}$ Water Quality Centre, DSIR Marine and Freshwater, PO Box 11-115, Hamilton, New Zealand \\ ${ }^{2}$ Chemistry Department, University of Waikato, Private Bag, Hamilton, New Zealand
}

\begin{abstract}
As part of a study designed to assess the impact of the pesticide technical chlordane on marine infauna, a 3 mo field trial was conducted to identify sensitive species and life stages and to determine the time-scale of their response. Technical chlordane was applied to a hitherto uncontaminated site to achieve a near-surface sediment concentration of about $7.5 \mathrm{ng}$ ( $\mathrm{g}$ dry fines) ${ }^{-1}$ After 5 to 13 tidal cycles, the density of common infaunal suspension and deposit feeding bivalves began to decline and continued to do so for at least a further 31 tides. Populations of Chione stutchburyi and Tellina liliana decreased to about 30 and $40 \%$ respectively of their initial densities. Analysis of the size structure of the 2 populations showed that the decrease resulted primarily from the loss of juveniles 0.5 to $2.5 \mathrm{~mm}$ in size. Juveniles within this size range gradually repopulated the site between Tides 44 and 112 , when chlordane residues in the near-surface sediment dropped to $3 \mathrm{ng}$ ( $\mathrm{g}$ dry fines $)^{-1}$ following a storm. Numerous post-metamorphic specimens of Chione stutchburyi (76) and Tellina liliana (163) were caught in drift nets placed around the study area, suggesting that the mobility of post-settlement juveniles may play an important role in reducing the density of small shellfish in contaminated sediment. The potential movement of post-settlement juveniles away from contaminated sediments could provide a useful technique for impact assessment.
\end{abstract}

\section{INTRODUCTION}

Many organic chemicals of anthropogenic origin are thought to be a threat to the marine environment. Most of these are pesticides or products of technical use; many contain chlorine (Ernst 1980).

Technical chlordane is a non-systemic contact and stomach poison used in the control of a diverse range of organisms, such as ants, beetles, grasshoppers, termites, cutworms and earthworms (Worthing \& Walker 1983). Like many other organochlorine pesticides (e.g. DDT, dieldrin, lindane), it is considered a major environmental contaminant (Callahan et al. 1979, Mowbray 1988) because of its worldwide distribution (Murty 1986, Kawano et al. 1988), its persistence in both terrestrial (Watanabe 1973, Parker et al. 1985) and aquatic ecosystems (Sanborn et al. 1976, Oloffs et al. 1978, Wood et al. 1986), its toxicity to a wide range of non-target organisms (Parrish et al. 1976, Cardwell et al. 1977, Mayer \& Ellersieck 1986, Srivastava \& Srivastava 1988) and its accumulation and biomagnification through the food chain (Butler 1971, Jansson et al. 1979, Kerkhoff \& De Boer 1982, Moilanen et al. 1982, Kawano et al. 1988, Norstrom et al. 1988). Mass spectral studies have shown that technical chlordane is comprised of more than 140 different chlorinated hydrocarbons (Dearth \& Hites 1991). How many of these contribute to its toxicity is not known.

Since 1946 more than 70000 tons of technical chlordane have been produced, of which 25 to $50 \%$ is thought still to exist in the environment unaltered (Dearth \& Hites 1991). Estuarine sediments are often rich in natural organic material and as a consequence act as traps for discharges of organic contaminants (Ernst 1984). Substances such as chlordane, which are sparingly soluble in water and have a high lipid solubility, will bind to detritus and the microscopic organic coating on estuarine sediments in preference to remaining in solution (Karickhoff 1984). Thus chlordane compounds will tend to concentrate in coastal environs and enter the food chain through organisms living in and on the sediments (Tanita et al. 1976, 
Environment Agency Japan 1983, Stephenson et al 1986, Fox et al. 1988, Phillips \& Spies 1988, Hume et al. 1989).

Studies reporting the effects of technical chlordane on natural assemblages of marine benthic invertebrates are few and are mainly concerned with its accumulation in oysters (e.g. Tanita et al. 1976, Rosales et al. 1979). More information is available on its acute toxicity to selected marine organisms (e.g. Parrish et al. 1976, McLeese \& Metcalfe 1980, McLeese et al. 1982), but such data are of limited use when forecasting sublethal effects and community response (Ernst 1980, Waldichuk 1989).

In this paper, we examine how the addition of technical chlordane to a hitherto uncontaminated site affected 2 natural populations of marine intertidal bivalves. One species, the New Zealand cockle Chione stutchburyi, is considered to be ecologically similar to the northern hemisphere species Cardium edule and Mercenaria mercenaria (Grace 1973). Adult C. stutchburyi live near the sediment surface and are typically described as suspension feeders. Adults of the other species, Tellina liliana, live 5 to $10 \mathrm{~cm}$ below the sediment surface and are generally regarded as deposit feeders. Both species are common members of intertidal sandflat communities in New Zealand. Our intent in applying technical chlordane was not to produce immediate mass mortalities within the study site, but rather to investigate the more subtle effects of low level contamination. In particular, we examine how the population structures of the 2 species in the impacted site were affected by the movement of post-settlement juveniles.

\section{MATERIALS AND METHODS}

Study sites. Two sites, each $300 \mathrm{~m}^{2}$, were established at mid-tide level on a sandflat near Wiroa Island $\left(37^{\circ} 01^{\prime} \mathrm{S}, 174^{\circ} 49^{\prime} \mathrm{E}\right)$, Manukau Harbour, New Zealand. The sites were separated by $20 \mathrm{~m}$ and were chosen for their similarity in physical appearance, wave exposure, and near-surface sediment composition. (Table 1). Both sites were treated similarly, except that one, the 'experimental site, was contaminated with technical chlordane, whereas the other, the 'reference' site, was not. Each site $(12 \times 25 \mathrm{~m})$ was divided into 10 equal sectors $(6 \times 5 \mathrm{~m})$. Sample locations within each sector were obtained from randomly derived cartesian coordinates. Coordinates were redrawn if the selected location fell within a $0.5 \mathrm{~m}$ radius of a previously sampled area to preclude any localised modification of the sediment or resident populations. Samples were taken before the application of technical chlordane and 1, 3, 5, 13, 19, 44, 71, 112, 199 tides later. Tides in Manukau
Harbour are semi-diurnal. The experiment was conducted from 3 July to 17 October 1989.

Materials. A paraffin-based solution of technical grade chlordane was provided by Forest Research Institute, Rotorua, New Zealand. Crystalline standards were used to quantify the following components: compound $C_{1}$ heptachlor, $\alpha$-chlordene, $\gamma$-chlordene, transchlordane, cis-chlordane, and trans-nonachlor. Where crystalline standards were not available, the response factors of closely related compounds with the same number of chlorine atoms were used: trans-chlordane for compound $\mathrm{K}$ and trans-nonachlor for cis-nonachlor (Norstrom et al. 1988). These 9 compounds constitute about $90 \%$ of the mass of chlorinated material in technical chlordane, the remainder being a mixture of byproducts and starting materials from its manufacture (Sovocool et al 1977, Callahan et al. 1979). Descriptions of these compounds are given by Smith et al. (1990) and Dearth \& Hites (1991).

Quantitative addition of chlordane to the experimental site was carried out as follows: sand collected adjacent to the experimental site was dried, loosened with a mortar and pestle, and then mixed with the technical chlordane solution in dichloromethane (DCM). The mixture was evaporated to dryness in a rotary evaporator and then diluted with more sand before being applied to the experimental site using a mechanical 'seed spreader'. The applied dosage was intended to be $80 \mathrm{ng} \mathrm{cm}^{-2}$ of technical chlordane.

Analysis of chlordane residues. Sediment cores were taken for chemical analysis from the study sites using a stainless steel corer, at the same time as the biological sampling. On each sampling occasion, three $10 \mathrm{~cm}$ deep cores $(2.1 \mathrm{~cm}$ diameter) were taken adjacent to each biological core. Sediments for chemical analysis were stored in polyethylene bags at $-20^{\circ} \mathrm{C}$ until analysed. Depth profiles of sediment chlordane residues were determined by sectioning cores $13 \mathrm{~cm}$

Table 1. Near-surface sediment composition (expressed as \% dry weight) at the 2 study sites. Sediment grain size at each site was determined by the methods described in Folk (1968) on a composite of 10 evenly spaced samples (ca $5 \mathrm{~m}$ apart) taken to a depth of $3 \mathrm{~cm}$. Reactive organic carbon was determined according to Gaudette \& Flight (1974)

\begin{tabular}{|lcc|}
\hline & $\begin{array}{c}\text { Experimental } \\
\text { site }\end{array}$ & $\begin{array}{c}\text { Reference } \\
\text { site }\end{array}$ \\
\hline$\%$ Mud & 6.2 & 5.2 \\
$\%$ Sand & 84.2 & 91.5 \\
$\%$ Gravel (predominantly shell) & 9.6 & 3.3 \\
Median grain size $(\Phi)$ & 1.84 & 2.16 \\
Inclusive graphic standard & 1.45 & 0.91 \\
deviation & & \\
\% Reactive organic carbon & 0.33 & 0.35 \\
\hline
\end{tabular}


diameter) from selected sites at depth intervals of $0-2 \mathrm{~cm}, 2-5 \mathrm{~cm}$ and $5-10 \mathrm{~cm}$.

All solvents used in the analyses of chlordane residues were redistilled in glass. Each sediment sample was thawed and then mixed well. An aliquot (ca $150 \mathrm{~g})$ was removed and air-dried at $40^{\circ} \mathrm{C}$. The dried sample was ground and sieved (500 $\mathrm{mm}$ mesh) to remove stones and shells, and a subsample $(40 \mathrm{~g}$ dry fines) placed in a glass thimble and extracted by Soxhlet apparatus for $6 \mathrm{~h}$ with DCM $(210 \mathrm{ml})$. (Note that some chlordane was detected in the rejected coarse material, but was insignificant in comparison to that obtained from the dry fines.)

Hexane $(4 \mathrm{ml})$ was then added to the extract and evaporated to ca $1 \mathrm{ml}$ using a rotary evaporator. Florisil $(2 \mathrm{~g})$, activated at $650^{\circ} \mathrm{C}$ and deactivated with $2 \%$ water, was packed into a glass column $(1 \mathrm{~cm}$ i.d.) topped with $2 \mathrm{~cm}$ of sodium sulphate. The extract was added to the column and eluted with hexane $(30 \mathrm{ml})$. This was evaporated to $1 \mathrm{ml}$ and then transferred to a tapered test tube with heptane rinses $(2 \times 1 \mathrm{ml})$. Sulphur was removed using bright copper wire, and the extract finally evaporated under a gentle stream of nitrogen to $1 \mathrm{ml}$, prior to analysis by gas chromatography and electron capture detection (GC-ECD).

Analysis was carried out using a Hewlett Packard 5890 GC equipped with an HP $7636 \mathrm{~A}$ automatic injector and a J\&W Scientific DB-1 fused silica capillary column. Carrier gas $\left(\mathrm{H}_{2}\right)$ flow rates were set at $40 \mathrm{~cm}$ $\mathrm{s}^{-1}$. A linear temperature program was used for the determination of retention indexes: initial oven temperature at $70^{\circ} \mathrm{C}$, held for $1 \mathrm{~min}$, ramped at $4^{\circ} \mathrm{C} \mathrm{min}{ }^{-1}$ to a final temperature of $280^{\circ} \mathrm{C}$. The injection port was held at $250^{\circ} \mathrm{C}$ and the detectors were held at $320^{\circ} \mathrm{C}$. Quantification was by comparison with an internal standard (lindane) which was added just prior to Soxhlet extraction. Field sample analyses were expressed as total recoverable chlordane' (CHL), defined here as the sum of: cis- and trans-chlordane, cis- and transnonachlor, heptachlor and compounds $\mathrm{C}$ and $\mathrm{K}$ (Miyazaki et al. 1985, Smith et al. 1990). Alpha- and gamma-chlordene were not quantified because of interfering peaks in their chromatograms. Compound $\mathrm{C}$ and heptachlor were occasionally subject to interfering chromatogram peaks that occurred when sample extracts were stored for long periods $(>5 \mathrm{wk})$ at $-20^{\circ} \mathrm{C}$. Missing values (46 out of 180 ) for those sample extracts were estimated from the average ratios of concentrations of heptachlor and compound $C$ to those of cis- and trans-chlordane for uncontaminated extracts, from samples collected at the same time. The $7 \mathrm{CHL}$ components constituted about $75 \%$ of the content of technical chlordane.

Macrofaunal analysis. One sediment core $(13 \mathrm{~cm}$ diameter, $12 \mathrm{~cm}$ depth) was taken from each sector on each sampling occasion. Immediately after collection, core samples were sieved (500 $\mu \mathrm{m}$ mesh) and the residue fixed in $5 \%$ formalin and $0.1 \%$ rose bengal in seawater. In the laboratory, macrofauna were sorted, identified to the lowest possible taxonomic level, counted, and preserved in $70 \%$ isopropanol. Preserved specimens of the bivalves Chione stutchburyi and Tellina liliana were sized to the nearest $0.1 \mathrm{~mm}$ (longest shell axis) with an ocular micrometer (individuals $<8 \mathrm{~mm}$ ) or vernier calipers. Shell lengths $<10 \mathrm{~mm}$ were pooled into $0.5 \mathrm{~mm}$ size classes; the remainder were grouped into $1 \mathrm{~mm}$ size classes because of the paucity of larger specimens.

One day after the application of technical chlordane, 8 drift nets were erected ( 2 upshore and 2 downshore of each study site) to assess the presence of fauna in the water column which are normally found in the benthos. Each net was ca $0.3 \mathrm{~m} \mathrm{high} \times 0.3 \mathrm{~m}$ wide $\times 1 \mathrm{~m}$ long and had a maximum mesh size of $270 \mu \mathrm{m}$. The nets were placed $20 \mathrm{~cm}$ above the bed and examined after one full tidal cycle. The exercise was repeated on the following tide. Specimens were processed as above. Because some fauna collected in the nets may have escaped during slack water or before the cod end of the net collapsed on tide reversal, no attempt was made to quantify the capture.

Data analysis. The significance of differences between sites or within a site over time was established using non-parametric techniques. The Mann-Whitney $U$-test was used for the analysis of 2 independent samples. The Kruskal-Wallis test was applied when more than 2 samples were compared. Multiple comparison tests (Tukey's rank sum) were conducted only after a significant $(p<0.05)$ Kruskal-Wallis test statistic was obtained. Details of the statistical methods used can be found in Conover (1980, p. 213-237) and SAS Institute (1987)

\section{RESULTS}

\section{Chlordane residues}

Sediment cores taken before the start of the experiment confirmed that pre-treatment concentrations of the 7 CHL components were below detection limits $\left[<0.06 \mathrm{ng}\right.$ ( $\mathrm{g}$ dry fines) $\left.{ }^{-1}\right]$ at both study sites.

Technical chlordane was applied to the surface of the

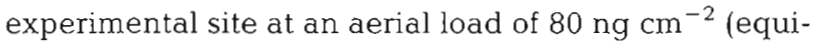

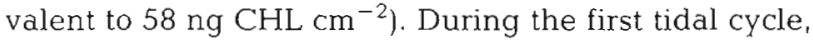
ca $36 \%$ of the pesticide disappeared from the site,

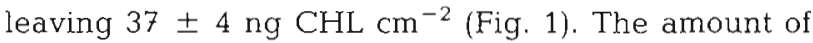
CHL in the sediment remained at or near this level for at least a further 43 tides, then declined to ca $20 \mathrm{ng}$ CHL cm ${ }^{-2}$ by Tide 71 (Kruskal-Wallis test, $\mathrm{p}<0.05$ ). 
No other change in CHL was detected throughout the remainder of the experiment.

Vertical concentration profiles (Fig. 2) show that there was initial movement of CHL downwards so that after the third tide more than $38 \%$ of $\mathrm{CHL}$ was found at depths greater than $2 \mathrm{~cm}$. Thereafter, the amount of CHL recovered from subsurface sediment $(2-10 \mathrm{~cm})$ remained relatively constant, whereas the mass of $\mathrm{CHL}$ in near-surface sediment $(0-2 \mathrm{~cm})$ declined markedly (ca $60 \%$ ) between Tides 44 and 71 (Mann-Whitney $U$ test, $\mathrm{p}<0.05)$.

Mean concentrations of $\mathrm{CHL}$ in the near-surface sediment ranged from 2.8 to $8.7 \mathrm{ng}$ ( $\mathrm{g}$ dry fines) ${ }^{-1}$ between Tides 3 and 71 (Fig. 2); lower mean concentrations were observed at depths of $2-5 \mathrm{~cm}[1.4$ to $1.9 \mathrm{ng}$ ( $\mathrm{g}$ dry fines) $)^{-1}$ ] and $5-10 \mathrm{~cm}$ [1.0 to $1.6 \mathrm{ng}$ ( $\mathrm{g}$ dry fines) $\left.{ }^{-1}\right]$.

No CHL component was detected in the reference site sediments throughout the experiment.

\section{Bivalve response}

Densities of Chione stutchburyi at the 2 study sites (Fig. 3) were not significantly different prior to the application of technical chlordane (Mann-Whitney $U$ test, $p>0.38$ ). At both sites, most ( 78 to $83 \%$ ) of the individuals were less than $5 \mathrm{~mm}$ in size (Fig. 4). The experimental site, however, contained more large $(\geq 20 \mathrm{~mm}$ ) individuals than the reference site (5.4 vs 1.8 individuals per core on average, Mann-Whitney $U$-test, $p<0.05)$. Pre-treatment densities of Tellina liliana were also similar at the 2 sites (Fig. 3) (Mann-Whitney $U$-test, $\mathrm{p}>0.34)$. Both assemblages were comprised principally ( 66 to $73 \%$ ) of small $(0.5$ to $2.5 \mathrm{~mm}$ ) individuals and few large $(\geq 20 \mathrm{~mm})$ specimens were observed $(<2$ per core on average) (Fig. 5).

Five to thirteen tides after the application of technical chiordane densities of Chione stutchburyi and Tellina liliana at the experimental site began to decline (Fig. 3). This trend continued for at least a further 31 tides, then reversed as individuals repopulated the site. Populations of $C$. stutchburyi and T liliana decreased to about 30 and $40 \%$ of their initial densities, respectively (Mann-Whitney $U$-tests, $p<0.05$ and 0.02 respectively). No such trend was apparent at the reference site for either species (Fig. 3).

Visual inspection of the size structure of the 2 populations (Figs. 4 \& 5) indicated that the decrease in density at the experimental site resulted primarily from the loss of juveniles 0.5 to $2.5 \mathrm{~mm}$ in size. Between Tides 5 and 44, the numbers of Chione stutchburyi and Tellina liliana within this size range dropped by 79 and $62 \%$, respectively (Fig. 3; Mann-Whitney U-test. $\mathrm{p}<0.001$ and 0.005 , respectively). In contrast, no

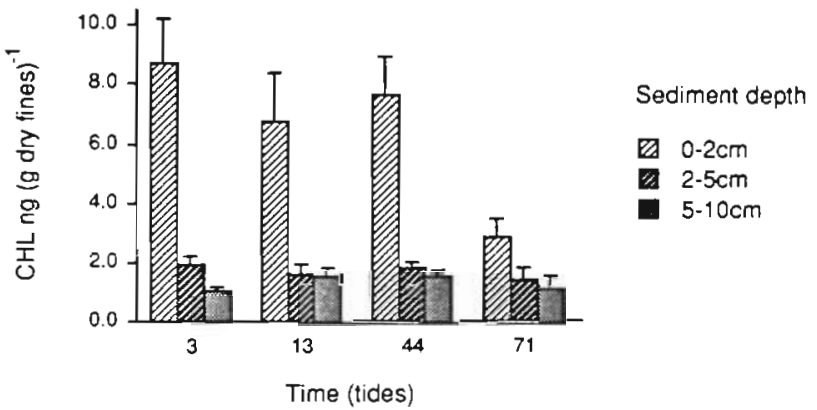

Fig. 1. Variations in the amount of total recoverable chlordane (CHL) in the sediment at the experimental site over time. CHL was applied at an aerial load of $58 \mathrm{ng} \mathrm{cm}^{-2}$ (not depicted). Results are expressed as mean \pm standard error

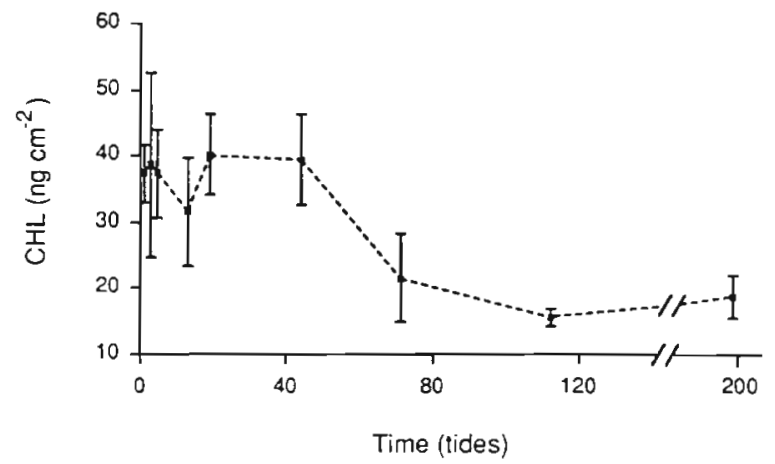

Fig. 2. Variations in the concentration of CHL at different depths of sediment over time at the experimental site. Results are expressed as mean \pm standard error

change was detected in the abundance of individuals $>2.5 \mathrm{~mm}$ in size (Mann-Whitney $U$-test, $p>0.10$ for both species). Juveniles 0.5 to $2.5 \mathrm{~mm}$ in size were also responsible for the repopulation of the experimental site (Fig. 3), increasing the mean densities of $C$. stutchburyi and T. liliana between Tides 44 and 112 by 3.5 and 4.3 individuals per core, respectively (Mann-Whitney $U$-test, $p<0.05$ and 0.02 , respectively). No change in the density of juveniles of either species was detected at the reference site between Tides 0 and 112 (Kruskal-Wallis test, $\mathrm{p}>0.95$ for both species!

Numerous post-metamorphic specimens of Chione stutchburyi (76) and Tellina liliana (163) were caught in the drift nets placed around the 2 study sites during Tides 3 and 5. All individuals caught were $<2.5 \mathrm{~mm}$ in size, except for two (both $T$. liliana) which measured 4 and $6 \mathrm{~mm}$.

Between Tides 112 and 199, bivalve density declined at both the experimental and reference sites by 49 and $40 \%$, respectively (Mann-Whitney $U$-test, p $<0.001$ and 0.005 , respectively). This decline coincided with a general decrease in the survivability of new recruits throughout the harbour (Thrush et al. 1990). 


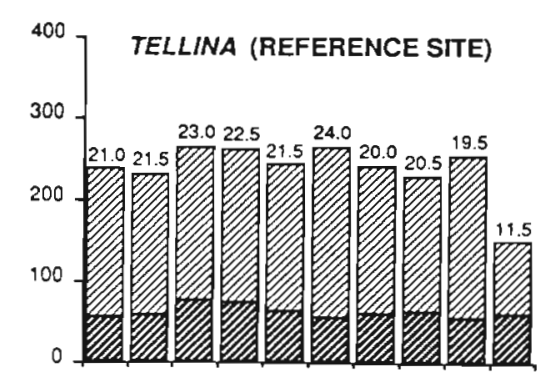

$\begin{array}{llllllllll}0 & 1 & 3 & 5 & 13 & 19 & 44 & 71 & 112 & 199\end{array}$
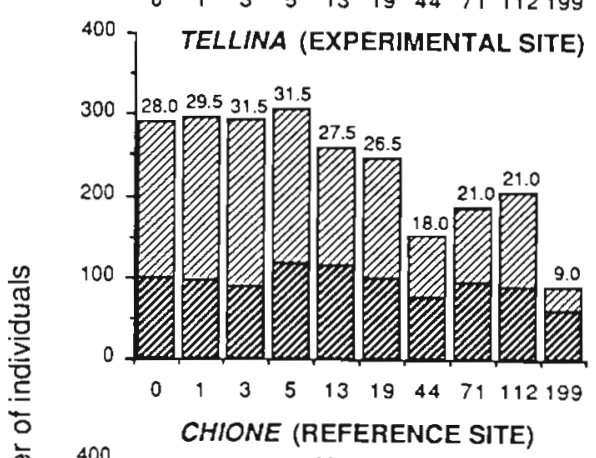

离 $\quad 400] 35.538 .5 \quad 32.036 .0$

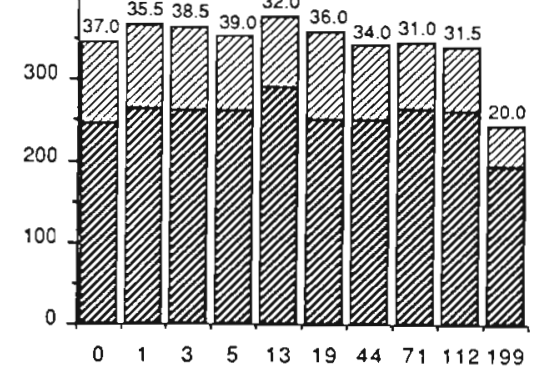

400 CHIONE (EXPERIMENTAL SITE)

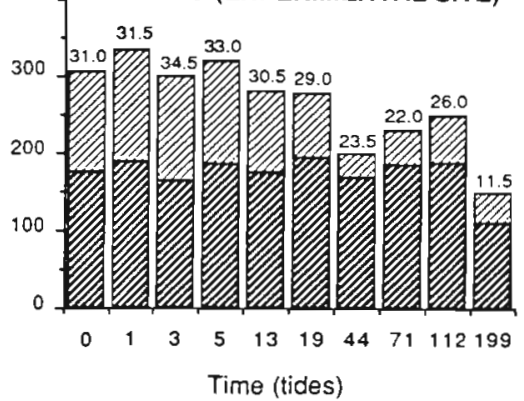

Size class

$0.5-2.5 \mathrm{~mm}$

$>2.5 \mathrm{~mm}$

Fig. 3. Tellina liliana and Chione stutchburyi. Total number found in 10 sediment cores from each site on each sampling occasion. Numbers of juveniles 0.5 to $2.5 \mathrm{~mm}$ in size are distinguished to show their temporal change in abundance. Median number of individuals per core is given at the top of each bar graph

\section{DISCUSSION}

A large initial loss of CHL from the experimental site was expected because of the way in which the pesticide was applied. Preliminary trials with the CHLcoated sand grains suggested that the loss could be as high as $50 \%$, which compared favourably with the

$36 \%$ loss observed during the actual experiment. Attempts to improve retention by spraying technical chlordane (dissolved in acetone) directly onto the surface sediments proved unsuccessful and had the undesirable effect of causing some surface dwelling gastropods (Amphibola crenata and Diloma subrosrata, in particular) to cease feeding and retreat into their shells. No visible change in faunal behavior was observed during the application of the CHL-coated sand grains.

Chlordane compounds attached to the sand grains were probably more susceptible to removal from the target area by processes such as resuspension and aqueous transport than were sediment residues during the remainder of the experiment. It is widely accepted that sediment sorption of uncharged organic chemicals is dependent on the amount of sediment organic matter (Karickhoff 1984). Thus some loss of CHL would have occurred during the first few tides as a result of redistribution from the applied sand, with low organic carbon, to more organically enriched silts in the experimental area. Once 'fixed', little loss of CHL from the sediment would be expected other than by erosion or bioaccumulation (Oloffs et al. 1973). This is analogous to land applications of pesticides, where runoff losses occur principally during the first significant rainfall, but thereafter are minimal because of incorporation in the soil matrix (Willis \& McDowell 1982).

Technical chlordane dispersed rapidly through the sediments following application. By the end of the third tide more than $38 \%$ of CHL was found at depths greater than $2 \mathrm{~cm}$ (i.e. below the depth of oxic sediment). Thereafter, the concentration of CHL in subsurface sediments $(2-5$ and $5-10 \mathrm{~cm}$ depth intervals) remained reasonably constant (Fig. 2), suggesting that CHL was transported downwards principally during the initial redistribution phase with the draw of interstitial water as the tidal flats drained.

The only significant loss of CHL from the sediments after the first tide occurred between Tides 44 and 71 (Fig. 1) when a storm passed through the study area. Callahan et al. (1979) have stated, based on a review of largely laboratory studies, that volatilisation and bioaccumulation may be important processes affecting the aquatic fate of chlordane compounds. We suggest that sediment transport processes, such as erosion and dilution (by uncontaminated sediment) may also have contributed to the observed change in CHL concentration, especially during the storm. No metabolite or other breakdown product of the CHL compounds (e.g. partially dechlorinated derivatives, oxychlordane, heptachlor epoxide) was detected in the sediment throughout the course of the experiment (Smith et al. unpubl.).

The mean concentration of CHL in the near-surface sediments of the experimental site between Tides 3 and 44 (when bivalve numbers were most affected) 

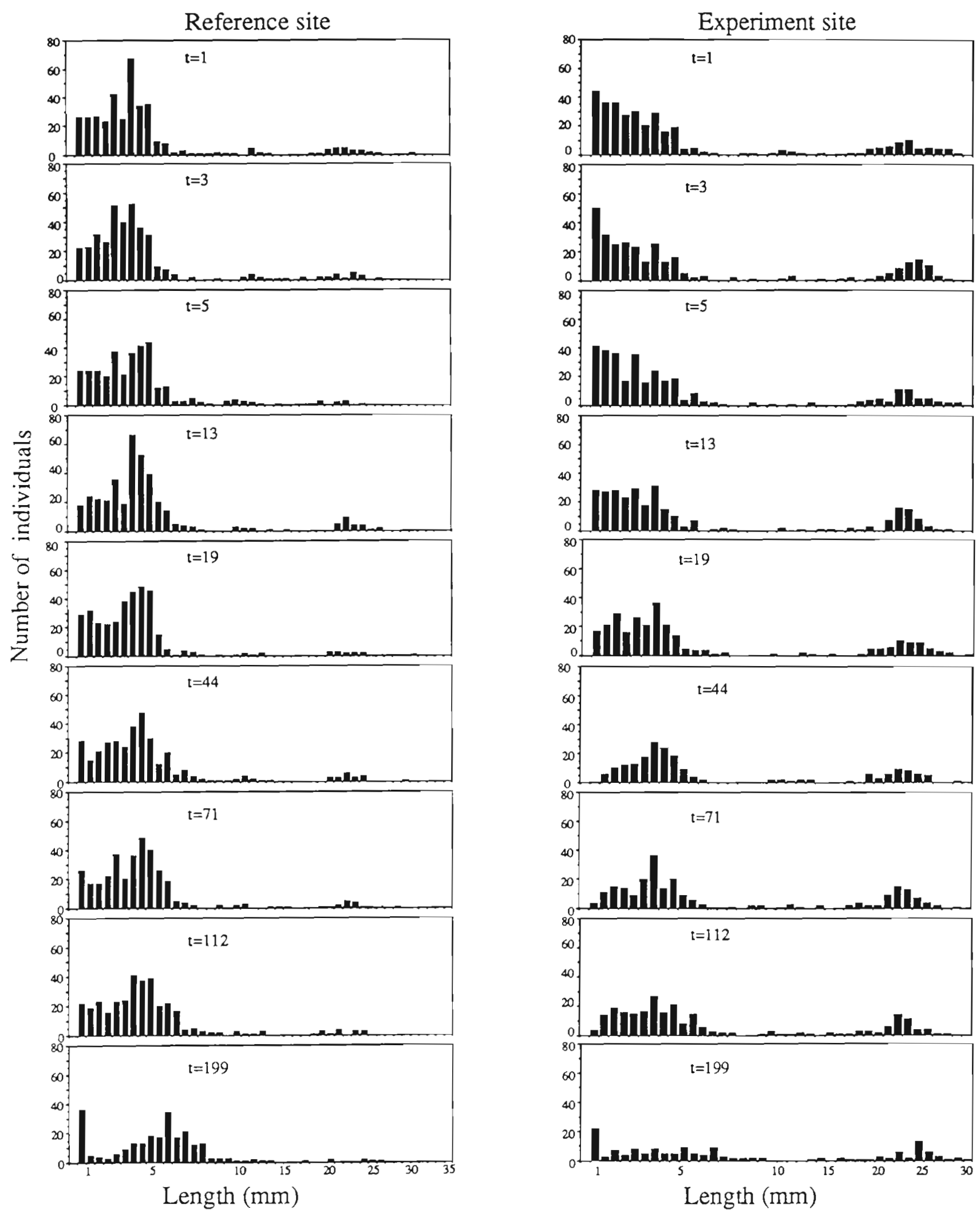

Fig. 4. Chione stutchburyi. Variations in the population structure at the experimental and reference sites over time. Numbers of individuals are those found in 10 sediment cores from each site on each sampling occasion. $t$ : number of tidal cycles after the application of technical chlordane 

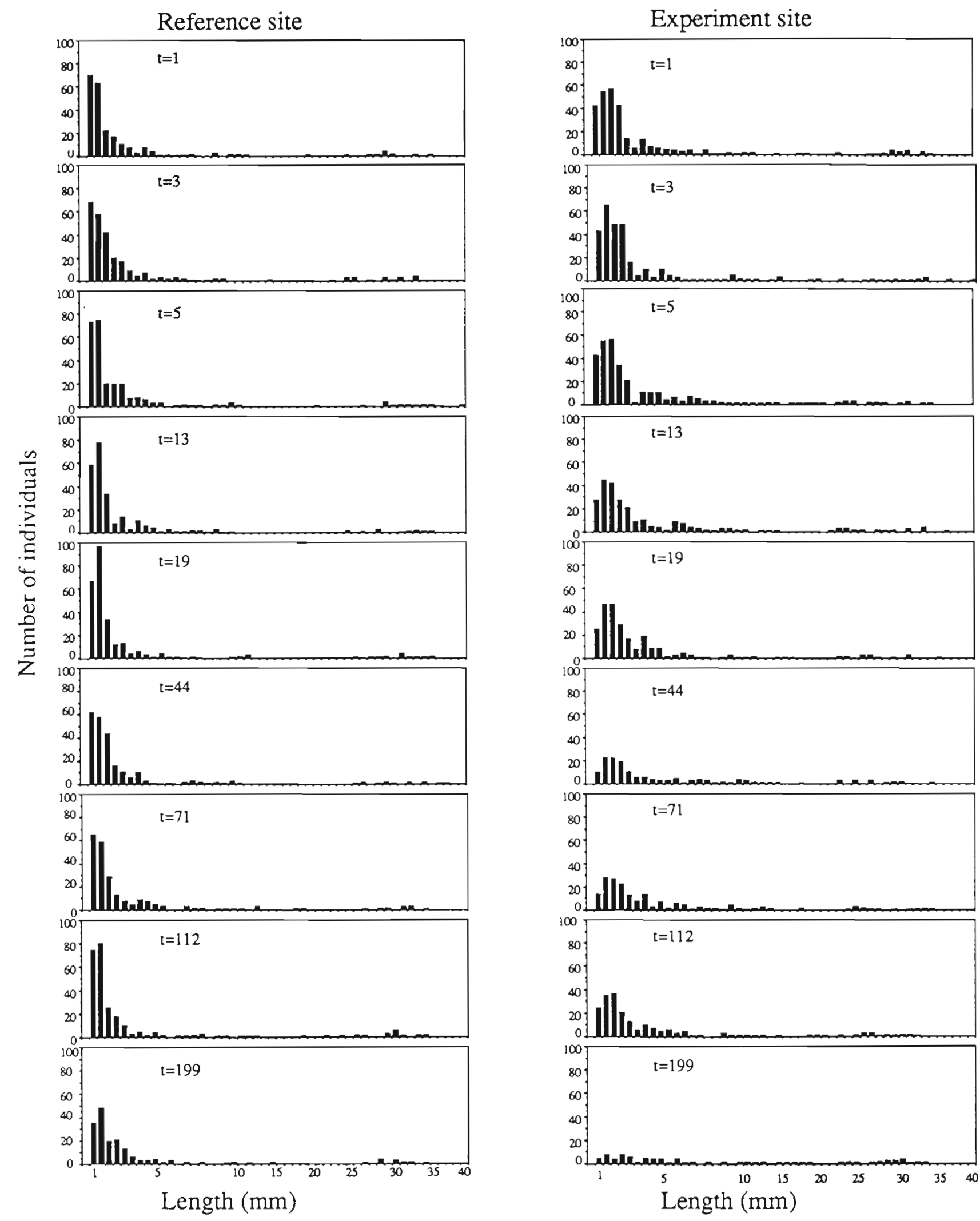

Fig. 5. Tellina liliana. Variations in the population structure at the experimental and reference sites over time. Numbers of individuals are those found in 10 sediment cores from each site on each sampling occasion. $t$ : number of tidal cycles after the application of technical chlordane 
ranged from 6.7 to $8.7 \mathrm{ng}$ (g dry fines) ${ }^{-1}$. This level of contamination is similar to that observed in areas of Manukau Harbour (Fox et al. 1988), San Francisco Bay (Phillips \& Spies 1988) and Tokyo Bay (Environment Agency Japan 1983). Concentrations 1 to 2 orders of magnitude higher have been measured in rivers and streams draining into coastal embayments (Phillips \& Spies 1988, Hirai \& Tomokuni 1989, Hume et al. 1989).

Both bivalve species showed a similar marked response to the test dosage. Each species declined in numbers by 30 to $40 \%$ between Tides 5 and 44 (Fig. 3), primarily as a result of juveniles 0.5 to $2.5 \mathrm{~mm}$ in size either emigrating from or dying in the experimental site. Juveniles within this size range gradually repopulated the site between Tides 44 and 112 , when a mean $\mathrm{CHL}$ of $3 \mathrm{ng}$ ( $\mathrm{g}$ dry fines) ${ }^{-1}$ was measured in the near surface sediments (Fig. 2).

Larval and juvenile organisms are often found to be more susceptible to chemical contaminants than are adult organisms (Rand \& Petrocelli 1985). This may be due to their greater body surface area (for absorption of contaminants) per unit body mass, their relatively higher metabolic rates, or differences in degree of development of detoxification or excretion mechanisms (Nimmo 1985). Although relatively few studies have compared the effects of pesticides on juvenile and adult bivalves, numerous examples of increased larval and juvenile sensitivity to organic contaminants are available in the marine literature. For example, Krebs \& Burns (1977) found juvenile salt-marsh crabs Uca pug$n a x$ to be sensitive to oil at concentrations 5 to 10 times lower than those affecting adults. Similar responses to oil have been obtained for a variety of amphipods (Linden 1976, Elmgren et al. 1983, Bonsdorff et al. 1990) and the gastropod Littorina littorea (Staveland 1979). Caldwell (1977) found that, for 9 pesticides, the zoeal stages of the Dungeness crab Cancer magister were 5 to 10 times more sensitive (mortality) than juvenile crabs and 10 to 100 times more sensitive than adult crabs. Numbers of juvenile clams Tresus capax and Macoma nasuta were significantly reduced when the insecticide carbaryl was experimentally applied to an intertidal mudflat (Armstrong \& Millemann 1974). Carbaryl has also been found to reduce the growth and survival of juveniles of the cockle clam Clinocardium nuttalli (Butler et al. 1968).

Whether the number of juveniles in the experimental site declined as a result of CHL-induced mortality, changes in behaviour, or both is not known. Exposure to pollutants, even in exceedingly low concentrations, can elicit behavioural responses which shift competitive balances, alter reproductive success, or weaken a prey's ability to escape predation (see reviews by Olla et al. 1980 and Sheehan 1984). Avoidance behaviour, in particular, could have contributed significantly to the observed loss. In this study, only individuals $\leq 2.5 \mathrm{~mm}$ in size declined in numbers; they were also the only size class (with the exception of 2 individuals) to be caught in drift nets placed around the 2 study sites. These small, highly mobile juveniles may have been able to discriminate between CHL-contaminated and uncontaminated sediments and actively avoided colonisation of, or escaped from, the impacted site. This hypothesis is supported principally by the observed repopulation of the impacted site after Tide 44 (Fig. 3) when the concentration of $\mathrm{CHL}$ in the near-surface sediment dropped by ca $50 \%$ (Fig. 1); no increase in juvenile abundance was detected at the reference site over the same time period.

Avoidance behaviour has been observed in a number of marine invertebrate taxa (Davenport 1977, Krebs \& Burns 1977, Saliba \& Vella 1977, Bonsdorff 1983, 1984), including the tellinid bivalve, Macoma balthica (McGreer 1979). The potential movement of postsettlement bivalves away from contaminated sediments could provide a useful technique for impact assessment. Many marine species have open populations which can be maintained by recruitment of larvae from adults living elsewhere (Underwood \& Fairweather 1989). The movement of juveniles away from impacted sites could prevent the persistence of populations, even where larvae do not show site selectivity.

The observed repopulation of the impacted site by post-settlement juveniles also demonstrates the importance of infaunal mobility in the colonisation of disturbed soft-bottom habitats. Juveniles of Tellina liliana and Chione stutchburyi have been observed to rapidly repopulate ray feeding pits (Thrush et al. 1991) and to colonise, although at a much slower rate, defaunated sediments (Thrush et al. unpubl.). Many species of bivalves are thought to undergo a second phase of pelagic dispersal after a more or less prolonged period of benthic existence (Sigurdsson et al. 1976, Lane et al. 1985, Yankson 1986, Sorlin 1988, Beukema \& de Vlas 1989). In this study, numerous post-metamorphic specimens of $T$. liliana and $C$. stutchburyi were caught in drift nets placed around the experimental and reference sites suggesting that these species can be added to the list. Other species of tellinid and venerid bivalves which are known to exhibit postlarval mobility include Abra alba, Donax vittatus, Gari fervensis, Macoma balthica, Tellina tenuis and Venerupis pullastra (Sigurdsson et al. 1976. Beukema \& de Vlas 1989).

Because juveniles of both Chione stutchburyi and Tellina hliana live and feed near the sediment surface, differences in their primary mode of feeding probably had little influence on the observed outcome. The siphon of C. stutchburyi is short and conical and would not allow juveniles 0.5 to $2.5 \mathrm{~mm}$ in size to filter outside of the contaminated sediment-water interface. In addi- 
tion, juveniles of $T$. liliana do not appear to be strict deposit feeders. Juveniles maintained in well-aerated laboratory aquaria often had their siphons extended into the water column, where they remained straight and relatively still for periods of $1 \mathrm{~h}$ or more. 'Olafsson (1986) has demonstrated that the tellinid bivalve Macoma balthica is capable of switching between deposit and suspension feeding modes and that this switching is associated with changes in water flow. Similar observations have been made by Bubnova (1972), who concluded that $M$. balthica commences suspension feeding in response to the increased amount of suspended matter present at high flow rates.

Although CHL had no detectable effect on adult numbers of either species, large Tellina liliana (20 to $40 \mathrm{~mm}$ ) accumulated 4 times more CHL than similar sized specimens of Chione stutchburyi [i.e. 14500 vs 3600 ng CHL ( $g$ fat wt) ${ }^{-1}$, respectively; authors' unpubl. data]. This difference may be attributable to their different modes of feeding, but may also be related to a differential ability to metabolise CHL. Leard et al. (1980) noted, for example, that species of fingernail clams have varying abilities to eliminate organochlorine pesticides. Boon et al. (1985) have suggested that varying physiological cycles may be responsible, at least in part, for the diversity in body burdens amongst polychaete worms exposed to organochlorine residues.

In conclusion, our results indicate that technical chlordane can reduce juvenile bivalve abundance in intertidal sediments at a relatively low level of exposure. However, because only one experimental and one reference site were studied, there is the possibility that the observed response was purely a location effect (e.g. Underwood 1989). Further experiments using replicated treatments could be conducted to corroborate these findings. However, in view of the large size of our study sites $\left(300 \mathrm{~m}^{2}\right)$, their close proximity, their initial similarity in both physical attributes and community structure, and the nature of the bivalve response, we feel that such an effect is unlikely and suggest that effort would be better spent examining the behavioural responses of the 2 species to CHL contamination.

\section{LITERATURE CITED}

Armstong, D. A., Millemann, R. E. (1974). Effects of the insecticide carbaryl on clams and some other intertidal mud flat animals. J. Fish. Res. Bd Can. 31: 466-469

Beukema, J. J., de Vlas, J. (1989). Tidal-current transport of thread-drifting postlarval juveniles of the bivalve Macoma balthica from the Wadden Sea to the North Sea. Mar. Ecol. Prog. Ser. 52: 193-200

Bonsdorff, E. (1983). Effects of experimental oil exposure on the fauna associated with Corallina officinalis $\mathrm{L}$. in intertidal rock pools. Sarsia 68: 149-155

Bonsdorff, E. (1984). Effects of experimental oil spills in intertidal rock pools. Ecol. Bull. 36: 154-164.
Bonsdorff, E., Bakke, T., Pedersen, A. (1990). Colonization of amphipods and polychaetes to sediments experimentally exposed to oil hydrocarbons. Mar. Pollut. Bull. 21: 355-358

Boon, J. P., van Zantvoort, M. B., Govaert, M. J. M. A. (1985). Organochlorines in benthic polychaetes (Nephtys spp.) and sediments from the southern North Sea. Identification of individual PCB components. Neth. J. Sea Res. 19: 93-109

Bubnova, N. P. (1972). The nutrition of the detritus-feeding mollusks Macoma balthica (L.) and Portlandia arctica (Gray) and their influence on bottom sediments. Oceanology 12: 899-905

Butler, J. A., Millemann, R. E., Stewart, N. E. (1968). Effects of the insecticide Sevin on survival and growth of the cockle clam Clinocardium nuttalli. J. Fish. Res. Bd Can. 25: 1621-1635

Butler, P. A. (1971). Influence of pesticides on marine ecosystems. Proc. R. Soc. Lond. B. 177: 321-329

Caldwell, R. S. (1977). Biological effects of pesticides on the dungeness crab. Ecol. Res. Ser. EPA-600/3-77-131

Callahan, M. A., Slimak, M. W., Gabel, N. W., May, I. P., Fowler, C. F., Freed, J. R., Jennings, P., Durfee, R. L., Whitmore, F. C., Maestri, B., Mabey, W. R., Holt, B. R., Gould, C. (1979). Water-related environmental fate of 129 priority pollutants. EPA-440/4-79-029a. Office of Water Planning and Standards, U.S. E.P.A., Washington, D.C.

Cardwell, R. D., Foreman, D. G., Payne, T R., Wilbur, D. J. (1977). Acute and chronic toxicity of chlordane to fish and invertebrates. EPA-600/3-77-019. U.S. Environmental Research Laboratory, Duluth, MN

Conover, W. J. (1980). Practical nonparametric statistics, 2nd edn. John Wiley \& Sons, New York

Davenport, J. (1977). A study of the effects of copper applied continuously and discontinuously to specimens of Mytilus edulis (L.) exposed to steady and fluctuating salinity levels. J. mar. biol. Ass. U.K. 57: 63-74

Dearth, M. A., Hites, R. A. (1991). Complete analysis of technical chlordane using negative ionization mass spectrometry. Environ. Sci. Technol. 25: 245-254

Elmgren, R., Hansson, S., Larsson, U., Sundelin, B., Boehm, P. D. (1983). The 'Tsesis' oil spill: acute and long-term impact on the benthos. Mar. Biol. 73: 51-65

Environment Agency Japan (1983). Chemicals in the environment. Off. Health Studies Rep. 9. Environment Agency, Tokyo

Ernst, W. (1980). Effects of pesticides and related organic compounds in the sea. Helgoländer Meeresunters. 33: 301-312

Ernst, W. (1984). Pesticides and technical organic chemicals. In: Kinne, O. (ed.) Marine ecology, Vol. V, Ocean management, Part 4. John Wiley \& Sons, Chichester, p. 1627-1709

Folk, R. L. (1968). Petrology of sedimentary rocks. Hemphills, Austin, Texas

Fox, M. E., Roper, D. S., Thrush, S. F. (1988). Organochlorine contaminants in surficial sediments of Manukau Harbour, New Zealand. Mar. Pollut. Bull. 13: 217-218

Gaudette, H. E., Flight, W R. (1974). An inexpensive titration method for the determination of organic carbon in recent sediments. J. Sedim. Petrol 44: 249-253

Grace, R. V. (1973). The benthic ecology of the entrance to the Whangateau Harbour, Northland, New Zealand, Ph.D. thesis, Department of Zoology, Univ. of Auckland

Hirai, Y., Tomokuni, K. (1989). Levels of chlordane in water and sediment of rivers around Saga City, Japan. Bull. environ. Contam. Toxicol. 42: 589-594

Hume, T. M., Fox, M. E., Wilcock, R. J. (1989). Use of organochlorine contaminants to measure sedimentation 
rates in estuaries: a case study from the Manukau Harbour. J. R. Soc. N.Z. 19: 305-317

Jansson, B., Vaz, R., Blomkvist, G., Jensen, S., Olsson, M. (1979). Chlorinated terpenes and chlordane components found in fish, guillemot and seal from Swedish waters. Chemosphere 8: 181-190

Karickhoff, S. W (1984). Organic pollutant sorption in aquatic systems. J. Hyd. Div., ASCE, 110: 707-735

Kawano, M., Tsuyoshi, I., Wada, T., Hidaka, H., Tatsukawa, R. (1988). Bioconcentration and residue patterns of chlordane compounds in marine animals: invertebrates, fish, mammals, and seabirds. Environ. Sci. Technol. 22: 792-797

Kerkhoff, M., De Boer, J. (1982). Identification of chlordane compounds in harbour seals from the coastal waters of the Netherlands. Chemosphere 11, 841-845

Krebs, C. T., Burns, K. A. (1977). Long-term effects of an oil spill on populations of the saltmarsh crab Uca pugnax. Science 197: 484-487

Lane, D. J. W., Beaumont, A. R., Hunter, J. R. (1985). Byssus drifting and the drifting threads of the young post-larval mussel Mytilus edulis. Mar. Biol. 84: 301-308

Leard, R. L., Grantham, B. J., Pessoney, G. F. (1980). Use of selected freshwater bivalves for monitoring organochlorine residues in major Mississippi stream systems, 1972-73. Pestic. Monitor. J. 14: 47-52

Linden, O. (1976). Effects of oil on the reproduction of the amphipod Gammarus oceanicus. Ambio 5: 36-37

Mayer, F. L., Ellersieck, M. R. (1986). Manual of acute toxicity: interpretation and data base for 410 chemicals and 66 species of freshwater animals. Resource Publ. 160, United States Department of the Interior, Fish and Wildlife Service, Washington, D.C.

McGreer, E. R. (1979). Sublethal effects of heavy metal contaminated sediments on the bivalve Macoma balthica (L.). Mar. Pollut. Bull. 10: 259-262

Mcleese, D. W., Metcalfe, C. D. (1980). Toxicities of eight organochlorine compounds in sediment and in seawater to Crangon septemspinosa. Bull environ. Contam. Toxicol. 25: $921-928$

McLeese, D. W., Burridge, L. E., van Dinter, J. (1982). Toxicities of five organochlorine compounds in water and in sediment to Nereis virens. Bull. environ. Contam. Toxicol. 28: $216-220$

Miyazaki, T., Yamagishi, T., Matsumoto, M. (1985). Selected ion monitoring method for the determination of residues of chlordane. J. Food. Hyg. Soc. Japan 26: 371-379

Moilanen, R., Pyysalo, H., Wickstrom, K., Linko, R. (1982). Time trends of chlordane, DDT, and PCB concentrations in pike (Esox lucius) and baltic herring (Clupea harengus) in the Turku Archipelago, Northern Baltic sea for the period 1971-1982. Bull. environ. Contam. Toxicol. 29: 334-340

Mowbray, D. L. (1988). Pesticide use in the South Pacific. UNEP Regional Seas Reports and Studıes No. 89. United Nations Environment Programme, Nairobi

Murty, A. S. (1986). Toxicity of pesticides to fish, Vol. 1. CRC Press, Boca Raton

Nimmo, D. R. (1985). Pesticides. In. Rand, G. M., Petrocelli, S. R. (eds.) Fundamentals of aquatic toxicology: methods and applications. Hemisphere Publishing Corporation, New York, p. 335-373

Norstrom, R. J., Simon, M., Murr, C. G., Schweinsburg, R. E. (1988). Organochlorine contaminants in arctic marine food chains: identification, geographical distribution, and temporal trends in polar bears. Environ. Scl. Technol. 22 $1063-1071$

'Olafsson, E. B. (1986). Density dependence in suspensionfeeding and deposit-feeding populations of the bivalve
Macoma balthica: a field experiment. J. Anum. Ecol. 55: $517-526$

Olla, B. L., Pearson, W. H., Studholme, A. L. (1980). Applicability of behavioral measures in environmental stress assessment. In: McIntyre, A. D., Pearce, J. B. (eds.) Biological effects of marine pollution and the problems of monitoring. Rapp. P.-v. Réun. Cons. int. Explor. Mer 179: $162-173$

Oloffs, P. C., Albright, L. J., Szeto, S. Y. (1978). Persistence of residues in water and sediment of a fresh-water lake after surface application of technical chlordane. J. Environ. Sci. Health B 13: 47-58

Oloffs, P. C., Albright, L. J., Szeto, S. Y., Lau, J. (1973). Factors affecting the behavior of five chlorinated hydrocarbons in two natural waters and their sediments. J. Fish. Res. Bd Can. 30: 1619-1623

Parker, L. W., Ryderwhi, J., Thomas, S., Whitford, W. G (1985). Effects of oxamyl and chlordane on the activities of nontarget soil organisms. Bio. Fert. Soils 1. 141-148

Parrish, P. R., Schimmel, S. C., Hansen, D. J., Patrick, J. M., Forester, J. (1976). Chlordane: effect on several estuarine organisms. J. Toxicol environ. Health 1. 485-494

Phillips, D. J. H., Spies, R. B. (1988). Chlorinated hydrocarbons in the San Francisco estuarine ecosystem. Mar. Pollut. Bull. 19: 445-453

Rand, G. M., Petrocelli, S. R. (1985). Introduction. In: Rand, G. M., Petrocelli, S. R. (eds.) Fundamentals of aquatic toxicology: methods and applications. Hemisphere Publishing Corporation, New York, p. 1-28

Rosales, M. T L., Botello, A. V., Bravo, H., Mandelli, E. F (1979). PCBs and organochlorine insecticides in oysters from coastal lagoons of the Gulf of Mexico. Bull. environ. Contam. Toxicol. 21: 652-656

Saliba, L. J., Vella, M. G. (1977). Effects of mercury on the behaviour and oxygen consumption of Monodonta articulata. Mar. Biol. 43: 277-282

Sanborn, J. R., Metcalf, R. L., Bruce, W. M., Po-Yung, L. (1976). The fate of chlordane and toxaphene in a terrestrial-aquatic model ecosystem. Environ. Entomol. 5: 533-538

SAS Institute Inc. (1987). Statistical analysis software, version 5.16. SAS Institute Inc., Cary, North Carolina

Sheehan, P. J. (1984). Effects on individuals and populations. In: Sheehan, P. J., Miller, D. R., Bulter, G. C., Bourdeau, Ph. (eds.) Effects of pollutants at the ecosystem level. John Wiley \& Sons, Chichester, p. 23-50

Sigurdsson, J. B., Titman, C. W., Davies, P. A. (1976). The dispersal of young post-larval bivalve molluscs by byssus threads. Nature, Lond. 262: 386-387

Smith, T J, Langdon, A. G., Wilkins. A. L., Wilcock, R. J., Coddington, J. M. (1990). A revised structure for compound ' 2 ' and $\mathrm{x}$-ray crystal structure of compound $\mathrm{C}_{\text {, }}$ components of technical chlordane. Aust. J. Chem. 43: $1581-1586$

Sorlin, T. (1988). Floating behaviour in the tellinid bivalve Macoma balthica (L.). Oecologia 77: 273-277

Sovocool, G. W., Lewis, R. G., Harless, R L., Wilson, N. K., Zehr, R. D. (1977). Analyses of technical chlordane by gas chromatography/mass spectrometry. Anal. Chem 49: $734-740$

Srivastava, A. K., Srivastava, A. K. (1988). Chlordane induced changes in carbohydrate metabolism of the Indian catfish Heteropneustes fossilis (Bloch). Bull. Inst. Zool. Acad. Sin. 27: $211-215$

Staveland, J. T. (1979). Effects on hatching in Littorina littorea after an oil spill. Mar Pollut. Bull. 10: 255-258

Stephenson, M., Smith, D., Ichikawa, G., Goetz, J., Martin, M. (1986). State mussel watch program: preliminary data 
report 1985-1986. Report from California Department of Fish \& Game to California State Water Resources Control Board, July 1986

Tanita, R., Johnson, J. M., Chun, M., Maciolek, J. (1976) Organochlorine pesticides in the Hawaii Kai Marina. Pestic. Monit. J. 10: 24-29

Thrush S. F., Pridmore, R. D., Hewitt, J. E., Cummings, V. J. (1991). Impact of ray feeding disturbances on sandflat macrobenthos: do communities dominated by polychaetes or shellfish respond differently? Mar Ecol. Prog. Ser. 69: 245-252

Thrush, S. F., Pridmore, R. D., Hewitt, J. E., Cummings, V. J., Latimer, G. J. (1990). Ecological monitoring programme for the Manukau Harbour: presentation of data collected up to February 1990. Tech. Rep. No. 8046, Water Quality Centre, Department of Scientific and Industrial Research, Hamilton, New Zealand

Underwood, A. J. (1989). The analyses of stress in natural populations. Biol. J. Linnean Soc. 37: 51-78

Underwood, A. J., Fairweather, P. G. (1989). Supply-side ecology and benthic marine assemblages. TREE 4: 16-20

This article was presented by J. Gray, Oslo, Norway
Waldichuk, M. (1989). Aquatic toxicology in management of marine environment quality: present trends and future prospects. In: Nriagu, J. O., Lakshminarayana, J. S. S. (eds.) Aquatic toxicology and water quality management. John Wiley \& Sons, New York, p. 7-22

Watanabe, I. (1973). Decomposition of pesticides by soil microorganisms-special emphasis on flooded soil condition. JARQ 7 15-18

Willis, G. H., McDowell, L. L. (1982). Review: pesticides in agricultural runoff and their effects on downstream water quality. Environ. Toxicol. Chem. 1. 267-279

Wood, L. W., Jones, P. A., Richards, A. (1986). Possible sediment scavenging of chlordane and contamination of the aquatic biota in Belmont Lake, New York. Bull. environ. Contam. Toxicol. 36: 159-167

Worthing, C. R., Walker, S. B. (eds.) (1983). The pesticide manual, a world compendium, 7 th edn. The British Crop Protection Council, Thornton, Heath

Yankson, K. (1986). Observations on byssus systems in the spat of Cerastoderma glaucum and C. edule. J. mar. biol. Ass. U.K. 66: 277-292

Manuscript first received: April 21, 1991

Accepted: August 15, 1991 